\title{
Helle Kannila - humanisti ja liberaali: henkilöhistoriaa kirjastopoliittiseen keskusteluun
}

\author{
Pirjo Tuomi \\ ptuomi09@gmail.com \\ https://orcid.org/0000-0003-2866-4418 \\ Asiasanat: Kannila, Helle; yleiset kirjastot; naisasialiike; elämäkertatutkimus
}

Helle Cannelin (vuodesta 1938 Kannila) tuli valituksi vuonna 1921 suomalaisen yleisen kirjastolaitoksen johtoon (Valtion kirjastotoimiston johtajaksi) vain 25vuotiaana. Valituksi tultuaan hän omisti kaiken tarmonsa - voidaan kai sanoa myös elämänsä - kirjastoasialle. Paitsi kirjastotoimiston johtajana (1921-1949) hän toimi Yhteiskunnallisen korkeakoulun kirjasto-opin lehtorina (1949-1963) ja muun muassa Kirjastolehden päätoimittajana. Koko uransa ajan hän kirjoitti ahkerasti kirjastoasioista sekä Kirjastolehteen että esimerkiksi Helsingin Sanomiin. Lisäksi hän oli yksi ahkerimmista Arvostelevan kirjaluettelon kirjoittajista.

Ennen kirjastoasialle antautumistaan Helle Cannelin oli aloittanut aktiivisen yhteiskunnallisen toiminnan. Hänet valittiin 1914 Suomalaisen Naisliiton johtokuntaan (19-vuotiaana) ja vuodesta 1920 lähtein hän kirjoitti säännöllisesti pakinoitsijana, kriitikkona ja pääkirjoittajana järjestön äänenkannattajaan Naisten Ääni -lehteen (Kannila, 1996, s. 8). Helle Cannelin liittyi jo varhain myös feministiseen Naisasialiitto Unioniin (per. 1892) ja esim. Maikki Friberg ja Lucina Hagman olivat hänelle tärkeitä vaikuttajanaisia (esim. Kauppi, 1976, ss. 41-42). Kannila tunnetaan merkittävänä Minna Canthin henkilön ja tuotannon tutkijana ja asiantuntijana. Canthin yhteiskunnallinen ajattelu ja näkemykset 
esimerkiksi naisten aseman parantamisesta ovatkin varmasti vaikuttaneet Kannilan omaan maailmankuvaan.

Poliittis-yhteiskunnallisen vaikuttamisen hän aloitti jo 21-vuotiaana Nuorsuomalaisen Puolueen radikaalisiiven perustamassa jakobiiniklubissa (Kauppi, 1976, s. 43). Kansalliseen Edistyspuolueeseen hän kuului perustamisesta asti (1918) toimien vuodesta 1922 puolueen hallituksessa. Puolueessa Kannila ajoi erityisesti samapalkkaisuutta ja kaikkien ammattien avaamista naisille (myös naispappeutta). Hän oli muotoilemassa puolueen ohjelmiin sukupuolten tasaarvoa koskevia kohtia.

Voidaan arvioida, että Kannilan kirjastopoliittiseen ajatteluun vaikutti merkittävästi kaikki se, mihin hänen nuoruudessa omaksumansa maailmankatsomukselliset näkemykset perustuivat. Kannilan nuoruuden ajan kirjoituksista ja puheista huokuu syvä paitsi humanistinen myös liberaali ajattelu. Vuodelta 1927 erään "akitatsioonipuheen" muistilapuista löytyy esimerkiksi hänen yhteiskunnallisen toimintansa päämääriä omalta osaltaan kuvaava muistiinpano: "ennen me naiset koetimme valmistaa lapsemme sopiviksi maailmaan, nyt meidän on tehtävä maailma sopivaksi lapsiamme varten" (SKS KIA, ei pvm., Muistilappu vuodelta 1927 . Kotelo 15.). Lasten, naisten tai muuten heikommassa asemassa olevien ihmisryhmien aseman parantaminen oli Kannilan näkemysten mukaan myös kirjastotoiminnan ydinaluetta.

Keskeistä Kannilan kirjastoajattelussa oli myös kirjastolaitoksen merkitys lukemisen edistämisessä. Kirjaston kirjallisuustarjonnan tuli olla paitsi kansansivistävää myös tarjota kaunokirjallisuutta kaikenlaisille lukijoille yhteiskunnallisesta asemasta ja sivistystasosta riippumatta. Kannilaa on arvosteltu voimakkaastikin hänen asenteistaan niin sanottua naisten viihdekirjallisuutta kohtaan. Nämäkin Kannilan näkemykset tulevat ymmärrettävämmiksi, kun huomioidaan hänen yhteiskunnallinen toimintansa ja ajattelunsa jo ennen varsinaista kirjastouraa.

Helle Kannilan ura ja toiminta kirjastoliikkeessä on hyvin dokumentoitu ja tutkittu. Vähemmän on kuitenkin tarkasteltu Kannilan kirjastoajattelun taustalla olevia tekijöitä. Mahdollisesti erityisesti Kannilan emansipatorinen toiminta monella sektorilla on vaikuttanut merkittävästi siihen, minkälaisen kirjastolaitoksen rakaentumisessa Kannila halusi olla mukana. Julkisen instituution rakentamisessa vastuullisella johdolla on strategioiden ja käytäntöjen luojana keskeinen asema (ks. esim. Boin \& Christensen, 2008, s. 281). Kirjastotoimisto ja Kannila henkilökohtaisesti katsoivatkin velvollisuudekseen vastata koko kirjastolaitoksen tulevasta kehityksestä ja suunnasta (ks. Cannelin, 1922, s. 22). Kannila ohjeisti kirjoituksillaan kirjastokenttää määrätietoisesti. Kannilan julkaistut lehtikirjoitukset, laaja kirjeenvaihto sekä muu säilynyt materiaali osoittavat toisaalta, että kuva, joka meillä on hänestä johtajana ja erityisesti 
hänen toimintansa taustalla olevista tekijöistä on vielä hyvin puutteellinen.

Esityksessä tarkastelen Helle Cannelin-Kannilan roolia yleisen kirjastolaitoksen organisoijana ja kehittäjänä huomioiden hänen henkilöhistoriaansa liittyviä tekijöitä. Pohdin lisäksi näiden tekijöiden antia määriteltäessä kirjastolaitoksen luonnetta humanismia korostavana instituutiona.

\section{Lähteet}

Boin, A., \& Christensen, T. (2008). The Development of Public Institutions: Reconsidering the Role of Leadership. Administration \& Society, 40(3), 271-297. https://doi.org/10.1177/ 0095399707313700

Cannelin, H. (1922). Kirjastonhoidon opas. Helsinki: Tietosanakirja.

Kannila, H. (1996). Ihmiset polveutuvat äideistäkin : Helle Kannila naisasiakirjoittajana. (M. Kuula, toim.). Helsinki: BTJ Kirjastopalvelu.

Kauppi, H. M. (1976). Helle Kannilan elämänpuut. Helsinki: Suomen kirjastoseura.

SKS KIA. (ei pvm.). Helle Kannilan arkisto. Muistilappu vuodelta 1927. Kotelo 15. 